\title{
Minimum prey and area requirements of the Vulnerable cheetah Acinonyx jubatus: implications for reintroduction and management of the species in South Africa
}

\author{
P. Lindsey, C.J. TA B bing, R. BRummer, H. DAvies-Mostert, M. Hay a R D \\ K. MARNEWICK and D. PARKER
}

\begin{abstract}
In South Africa there are efforts to manage reintroduced subpopulations of the Vulnerable cheetah Acinonyx jubatus in small reserves $\left(10-1,000 \mathrm{~km}^{2}\right)$ as a managed metapopulation. We estimated areas required to support cheetahs given varying prey densities, prey profiles and presence/absence of competing predators. A recent population and habitat viability assessment indicated that 20 subpopulations of 10 cheetahs or 10 subpopulations of 15 cheetahs are required to retain $90 \%$ of the heterozygosity of free-ranging cheetahs and to overcome stochastic events in the absence or presence of lions Panthera leo, respectively. We estimate that $203 \pm \mathrm{SE} 42 \mathrm{~km}^{2}$ (range $48-466 \mathrm{~km}^{2}$ ) is required to support 10 cheetahs in the absence of lions, whereas $703 \pm \mathrm{SE} 311 \mathrm{~km}^{2}\left(166-2,806 \mathrm{~km}^{2}\right)$ is required to support 15 cheetahs given equal numbers of lions, and $2,424 \pm \mathrm{SE} 890 \mathrm{~km}^{2}\left(727-3,739 \mathrm{~km}^{2}\right)$ given equal numbers of leopards Panthera pardus, spotted hyaenas Crocuta crocuta, wild dogs Lycaon pictus and lions. Existing subpopulations of cheetahs generally occur at densities higher than our mean predicted densities but usually within the range of predicted densities. The large area requirements of cheetahs have implications for the development of the managed metapopulation. Sourcing reintroduction sites of the sizes required to support recommended subpopulation sizes will be difficult. Consequently, innovative measures to increase the carrying capacity of reserves for cheetahs and/or to enlarge reserves will be required. Managers may be forced to stock cheetahs close to or beyond the carrying capacity of
\end{abstract}

P. LiNDSEY (Corresponding author) Mammal Research Institute, University of Pretoria, Pretoria, 0028, South Africa, Endangered Wildlife Trust, Johannesburg, South Africa, and Nature Conservation Trust, Alma, South Africa. E-mail palindsey@gmail.com

C.J. TAmbling Centre for African Conservation Ecology, Department of Zoology, Nelson Mandela Metropolitan University, Port Elizabeth, South Africa

R. Brummer, H. Davies-Mostert and K. Marnewick Endangered Wildlife Trust, Johannesburg, South Africa, and Nature Conservation Trust, Alma, South Africa

M. Hayward Australian Wildlife Conservancy, Nichol's Point, Victoria, Australia

D. PARKER Wildlife \& Reserve Management Research Group, Department of Zoology \& Entomology, Rhodes University, Grahamstown, South Africa

Received 12 April 2010. Revision requested 27 July 2010.

Accepted 24 August 2010. First published online 31 August 2011. their reserves. Consequently, careful management of reintroduced subpopulations will be required to prevent declines in prey populations.

Keywords Acinonyx jubatus, cheetah, fences, metapopulation, reintroduction, South Africa

\section{Introduction}

Conserving large predators is challenging, partly be$\checkmark$ cause of their large area requirements (Linnell et al., 2001). Given expanding human populations and increasing competition for land, predator conservation must be attempted in highly modified habitats (as is being achieved with some success in Europe; Breitenmoser, 1998) or in increasingly small fragments of natural habitat. In South Africa natural habitat is increasingly fragmented because of expanding human populations, the development of mines, land clearing for agriculture and urban expansion, and the proliferation of predator-proof fences on ranch lands (Marnewick et al., 2007; Lindsey et al., 2009a). However, potential exists for predator conservation on private lands because of the increased development of privately owned, fenced game reserves (Davies-Mostert et al., 2009; Marnewick et al., 2009).

Because of edge effects naturally occurring populations of African predators are disappearing from small- to medium-sized habitat patches in many parts of Africa (36-3,900 km², Woodroffe \& Ginsberg, 1998). African wild dogs Lycaon pictus, for example, are disappearing from habitat patches smaller than c. $3,600 \mathrm{~km}^{2}$ (Woodroffe \& Ginsberg, 1998). Boundary fencing reduces edge effects by reducing human incursion into protected areas and the movement of wildlife into adjacent unprotected lands (Lindsey et al., in press). Consequently, perimeter fencing has permitted the effective conservation of predators on smaller habitat fragments than would otherwise be possible. The reintroduction of predators into fenced reserves is a particularly common practice in South Africa (Hayward et al., 2007b; Hunter et al., 2007; Funston, 2008; Gusset et al., 2008; Davies-Mostert et al., 2009). Reintroduced populations of African wild dogs, for example, occur in eight reserves in South Africa, comprising $3,652 \mathrm{~km}^{2}$ and containing c. $33 \%$ of the wild population (Davies-Mostert et al., 2009; P. Lindsey, 
unpubl. data). Lions Panthera leo have been reintroduced into at least 27 reserves covering an area of $5,702 \mathrm{~km}^{2}$, resulting in the expansion of the free-ranging population by 460 individuals (12-17\%; Funston, 2008). Similarly, cheetahs Acinonyx jubatus (categorized as Vulnerable on the IUCN Red List; Durant et al., 2008) have been reintroduced into 37 reserves covering an area of $7,744 \mathrm{~km}^{2}$, resulting in the expansion of the wild population by c. 258 individuals, or c. $22-33 \%$ (P. Lindsey, unpubl. data). When alluding to the expansion of wild populations of cheetahs and lions we refer to cases where individuals of the two species are non-captive and hunt for themselves even if constrained by fences in some cases. Freeranging refers to wild populations that are not contained within a specific fenced area.

Reintroductions have, however, proceeded without due consideration of the area requirements of the predator species in question and in some cases steep declines in prey populations have followed (Power, 2002; Tambling \& du Toit, 2005; Hayward, 2008; Lehmann et al., 2008). For example, wild dogs have been removed from the smallest reserves into which they were reintroduced because of perceptions of excessive impact on prey populations (Nambiti Conservancy, $83 \mathrm{~km}^{2}$; Karongwe Game Reserve, $80 \mathrm{~km}^{2}$; Shamwari Game Reserve, $180 \mathrm{~km}^{2}$; Davies-Mostert et al., 2009). Similarly, cheetahs were removed from the $156 \mathrm{~km}^{2}$ Suikerbosrand Nature Reserve after they caused dramatic declines in prey populations (Pettifer, 1981).

Efforts have been made to assess the minimum area requirements of some predators for reintroductions, including wild dogs (Lindsey et al., 2004) and lions (Power, 2002; Lehmann et al., 2008). As yet, however, no attempt has been made to estimate the minimum area requirements of cheetahs. During a National Conservation Action Planning exercise in 2009 the decision was taken to manage reintroduced subpopulations of cheetahs in South Africa as a metapopulation (Lindsey \& Davies-Mostert, 2009). This decision follows the successful establishment and development of a managed metapopulation of wild dogs in South Africa after a population and habitat viability assessment (PHVA) workshop in 1998 (Mills et al., 1998; Davies-Mostert et al., 2009). A PHVA workshop was held in 2009 to identify the number and size of subpopulations of cheetahs required to ensure demographic and genetic viability (defined as the retention of $90 \%$ of the heterozygosity of free-ranging populations of cheetahs in South Africa over a period of 50 years). The results of the PHVA indicated that 10 subpopulations of 15 individuals would be required where lions occur, or 20 subpopulations of 10 individuals where lions are absent, given translocation to mimic dispersal once every 2 years (Lindsey et al., 2009a). The PHVA modelling implicitly incorporates interspecific impacts such as predation of cheetah cubs by competing predators. The mean size of reintroduced populations of cheetahs in South Africa is $<_{10}$ individuals $(6.60 \pm \mathrm{SE} 1.17)$, indicating that the establishment of larger subpopulations will be required to achieve viability for a managed metapopulation (Lindsey et al., 2009b). Planning for the development of the metapopulation is hampered by a lack of understanding of the areas required to support subpopulations of cheetahs of various sizes. Free-ranging cheetahs utilize home ranges of $126-1,156 \mathrm{~km}^{2}$ in southern Africa (Broomhall et al., 2003; Marker et al., 2008), although the mean size of reserves used for reintroductions in South Africa has been much smaller.

Here we estimate the minimum area requirements of cheetahs under various scenarios, based on prey availability, to assist with conservation planning. Our findings suggest that achieving viability in the managed metapopulation will be difficult because of a shortage of sufficiently large reserves. We suggest a number of potential management interventions that could assist in striving for viability for the metapopulation, including: promoting the formation of larger reserves, augmenting prey populations when they become depleted to allow the conservation of larger subpopulations in small reserves, manipulation of the densities of other predators to reduce competition and predation, and increasing connectivity of cheetah subpopulations in fenced reserves with free-ranging populations.

\section{Methods}

We obtained data on the prey profiles of cheetahs and other large predators from as many South African reserves as possible (12 in all), from published and unpublished sources, providing representation from a broad array of habitat, rainfall and prey species composition scenarios. We standardized dietary data by calculating the percentage biomass comprised by each prey species. We assumed that each individual prey animal killed weighed 0.75 of standard female mass (Stuart \& Stuart, 1991), after Coe et al. (1976), to take into account calves and subadults eaten. For the Kruger National Park data, where prey profiles were presented in the source as the number of adults and juveniles of each species killed, with no gender distinction, adults were assumed to equal the female mass, and juveniles 0.33 of female mass. For each reserve where we had a cheetah diet profile we used estimates of prey density from the same time period, or as close as possible before or after. Data from aerial censuses were adjusted for undercounting of small and cryptic species (Redfern et al., 2002) using correction factors presented by Owen-Smith \& Mills (2008) and Bothma (2002).

\section{Reserves with cheetahs but no other large predators}

Cheetahs require less food per day to survive than other large African carnivores and published estimates of their requirements range from $1.4 \mathrm{~kg}$ day $^{-1}$ (Mills et al., 2004) to $2.8 \mathrm{~kg} \mathrm{day}^{-1}$ (Frame, 1999), although females with older cubs 
can consume as little as $0.4 \mathrm{~kg} \mathrm{day}^{-1}$ (Mills et al., 2004). We assume that a cheetah requires on average $2.1 \mathrm{~kg} \mathrm{day}^{-1}$ (Mills \& Biggs, 1993; Owen-Smith \& Mills, 2008). We account for juveniles by multiplying the estimate of $2.1 \mathrm{~kg}^{\text {day }}{ }^{-1}$ by 0.75 , following Owen-Smith \& Mills (2008). We estimated the edible portion of prey carcasses following Bissett \& Bernard (2007), who suggest that $67 \%$ of prey items $>80 \mathrm{~kg}, 90 \%$ of prey items of $5-80 \mathrm{~kg}$ and $100 \%$ of prey items $<5 \mathrm{~kg}$ are consumed by cheetahs.

Given the prey profiles (Table 1), our estimates of consumption rate per day and edible carcass proportions, we calculated the biomass of each of the two most important prey species that would feed each of the populations of cheetahs for 1 year. We then calculated the number of individuals of each prey item $(K)$ in the diet of one cheetah per year. Sustainable number and area calculations follow Lindsey et al. (2004). Assuming that offtake by cheetahs will comprise a sustainable set amount each year we calculated the maximum sustainable yield of offtake by cheetahs as $M S Y_{\text {cheetah }}=\left(r_{m}{ }^{\star} K\right) / 4$ where $r_{m}$ is the maximum population growth rate of each prey item and $K$ is the number of prey items consumed (offtake; Caughley, 1977). The intrinsic growth rate $\left(r_{m}\right)$ of each population was calculated using $1.5 W^{-0.36}$ (Caughley \& Krebs, 1983), where $W$ is the standard female weight of each prey item (Bothma, 2002). Intrinsic rates of increase were estimated to be: blesbok Damaliscus pygargus, 0.33; eland Tragelaphus oryx, 0.17; gemsbok Oryx gazella, 0.22; hartebeest Alcelaphus buselaphus, 0.27; impala Aepyceros melampus, o.38; kudu Tragelaphus strepsiceros, 0.24; nyala Tragelaphus angasii, 0.34; springbok Antidorcas marsupialis, 0.41; waterbuck Kobus ellipsiprymnus, o.23; warthog Phacochoerus africanus, 0.34; wildebeest Connochaetes taurinus, 0.23; and zebra Equus burchelli, o.19.

$M S Y_{\text {cheetah }}$ indicates the maximum number of individual prey animals removed that should be sustainable based on growth rates expressed by $r_{m}$. Using the density of each dominant prey item in each reserve where the diet profile was constructed (Table 2), we calculated the minimum area that would be required to sustain reintroduced populations of cheetahs. We assume that the prey species with the higher area requirement will be the limiting species and will drive the area requirements for cheetah reintroductions (Lindsey et al., 2004).

To assess the feasibility of augmenting prey populations to achieve higher densities of cheetahs we calculated the increase in prey numbers of the two dominant prey species that would be required to support subpopulations of 10 cheetahs in 100,200 and $300 \mathrm{~km}^{2}$. Using the equations derived above we set the area values to the above levels and calculated the required density for the two dominant prey items. We subtracted the observed density of the prey species from the expected density to obtain a net change in density required to achieve 10 cheetahs in each specified area. Using the area of each reserve we calculated the population augmentation required from the estimated required increases in prey densities. We calculated the cost that would be incurred (in USD) for the required prey population augmentations based on mean prices at auctions for live wild ungulate species in South Africa in 2009: eland, USD 694; gemsbok, 686; impala, 115; kudu, 330; nyala, 742; springbok, 114; waterbuck, 618; warthog, 89; and wildebeest, 231 (Wildlife Ranching South Africa, unpubl. data).

\section{Reserves where other large predators are present}

Cheetahs lose 13.1\% (Caro, 1994), 11.8\% (Mills et al., 2004), 9.5\% (Radloff \& du Toit, 2004) and 3.5\% (Bissett \& Bernard, 2007) of their kills to kleptoparasitism in the Serengeti, Kruger, Mala Mala and Kwandwe respectively. Based on these estimates, and assuming that the majority of kleptoparasitism would occur in the presence of spotted hyaenas Crocuta crocuta, we set three levels of kleptoparasitism for prey profiles depending on the resident large carnivore assemblage in the reserve from which the prey profiles were derived. For reserves where both lions and spotted hyaenas are present we set kleptoparasitism to $11.8 \%$ (Mills et al., 2004), and for reserves where lions occur in the absence of spotted hyaenas we set kleptoparasitism to 3.5\% (Bissett \& Barnard, 2007) and where no large predators were present we set kleptoparasitism to zero.

Using these estimates of kleptoparasitism we reestimated the numbers of prey, and hence area, required for each reserve for the incremental introduction of cheetahs. Cheetahs in areas with other large predators will also lose access to food because other large predators will compete for similar prey species, depending on the degree of dietary overlap. Using reserves where the prey profiles of cheetah and other large carnivores were known we assessed overlap of prey profiles using Pianka's index:

$$
O_{j k}=\sum_{i}^{n} P_{i j} P_{i k} / \sqrt{\sum_{i}^{n} P_{i j}^{2} \sum_{i}^{n} P_{i k}^{2}},
$$

where $P_{i}$ is the frequency of occurrence of prey item $i$ in the diet of species $j$ and $k$ (Pianka, 1973). We calculated the biomass consumed by each other large predator from the prey profiles in the same manner as those used for cheetah.

Daily consumption rates of the four other large predators were taken from Owen-Smith \& Mills (2008) and we used 0.75 of this weight to account for juveniles in the population (Owen-Smith \& Mills, 2008). The proportion of prey carcasses that are edible for lions and spotted hyaenas was taken from Funston et al. (1998), and for cheetahs and wild dogs from Bissett \& Barnard (2007). The MSY required to support other large predators was calculated using the dominant two prey items of cheetahs and the same 
TABLE 1 Sample sizes (number of kills per predator species per study) used to estimate prey profiles of cheetah Acinonyx jubatus and four other large predators in 12 South African reserves, and percentage biomass contribution (in parentheses) of the two most important species in the prey profile of each predator.

\begin{tabular}{|c|c|c|c|c|c|}
\hline Reserve & $\begin{array}{l}\text { Cheetah } \\
\text { Acinonyx jubatus }\end{array}$ & $\begin{array}{l}\text { Leopard } \\
\text { Panthera } \\
\text { pardus }\end{array}$ & $\begin{array}{l}\text { Lion } \\
\text { Panthera } \\
\text { leo }\end{array}$ & $\begin{array}{l}\text { Spotted hyaena } \\
\text { Crocuta } \\
\text { crocuta }\end{array}$ & $\begin{array}{l}\text { Wild dog } \\
\text { Lycaon } \\
\text { pictus }\end{array}$ \\
\hline $\begin{array}{l}\text { Hluhluwe- } \\
\text { iMfolozi }\end{array}$ & $\begin{array}{l}136^{1} \\
\text { Nyala Tragelaphus } \\
\text { angasii }(40.0)^{1} \\
\text { Impala Aepyceros } \\
\text { melampus }(18.5)^{1}\end{array}$ & $\begin{array}{l}64^{1} \\
\text { Nyala }(30.5)^{1} \\
\text { Kudu Tragelaphus } \\
\text { strepsiceros }(14.8)^{1}\end{array}$ & $\begin{array}{l}225^{1} \\
\text { Buffalo Syncerus } \\
\text { caffer }(48.1)^{1} \\
\text { Wildebeest } \\
\text { Connochaetes } \\
\text { taurinus }(15.5)^{1}\end{array}$ & $\begin{array}{l}113^{2} \\
\text { Zebra Equus } \\
\text { burchelli }(25.9)^{2} \\
\text { Kudu }(22.7)^{2}\end{array}$ & $\begin{array}{l}19^{2} \\
\text { Nyala }(58.8)^{3} \\
\text { Zebra }(22.2)^{3}\end{array}$ \\
\hline Jubatus & $\begin{array}{l}54^{3} \\
\text { Kudu (31.0) } \\
\text { Eland Tragelaphus } \\
\text { oryx (17.1) }\end{array}$ & No data & Absent & Absent & Absent \\
\hline Karongwe & $\begin{array}{l}137^{4} \\
\text { Impala (65.6) } \\
\text { Kudu (19.5) }\end{array}$ & No data & $\begin{array}{l}590^{5} \\
\text { Kudu (25.0) } \\
\text { Giraffe Giraffa } \\
\text { camelopardalis (24.8) }\end{array}$ & No data & Absent \\
\hline Klaserie & $\begin{array}{l}27^{6} \\
\text { Impala (60.6) } \\
\text { Waterbuck Kobus } \\
\text { ellipsiprymnus }(11.9)^{7}\end{array}$ & $\begin{array}{l}88^{6} \\
\text { Impala (63.9) } \\
\text { Waterbuck (15.5) }\end{array}$ & No data & No data & No data \\
\hline Kruger & $\begin{array}{l}68^{7} \\
\text { Impala }(47.0) \\
\text { Zebra }(20.7)\end{array}$ & $\begin{array}{l}63^{8} \\
\text { Impala (56.4) } \\
\text { Reedbuck Redunca } \\
\text { arundinum (30.2) }\end{array}$ & $\begin{array}{l}111^{8} \\
\text { Zebra }(47.1) \\
\text { Impala }(17.1)\end{array}$ & $\begin{array}{l}27^{8} \\
\text { Kudu (43.9) } \\
\text { Impala (12.3) }\end{array}$ & $\begin{array}{l}52^{8} \\
\text { Impala (50.6) } \\
\text { Kudu (38.2) }\end{array}$ \\
\hline Kwandwe & $\begin{array}{l}367^{9} \\
\text { Kudu (50.3) } \\
\text { Springbok Antidorcas } \\
\text { marsupialis (8.5) }\end{array}$ & No data & $\begin{array}{l}350^{9} \\
\text { Kudu (35.5) } \\
\text { Eland (22.2) }\end{array}$ & Absent & $\begin{array}{l}148^{9} \\
\text { Kudu (84.7) } \\
\text { Hartebeest } \\
\text { Alcelaphus } \\
\text { buselaphus (4.4) }\end{array}$ \\
\hline Madikwe & $\begin{array}{l}56^{10} \\
\text { Kudu (26.8) } \\
\text { Wildebeest (21.4) }\end{array}$ & $\begin{array}{l}26^{10} \\
\text { Kudu }(34.0) \\
\text { Impala }(26.5)\end{array}$ & $\begin{array}{l}258^{10} \\
\text { Wildebeest (24.0) } \\
\text { Giraffe (19.6) }\end{array}$ & No data & $\begin{array}{l}218^{10} \\
\text { Kudu (50.8) } \\
\text { Waterbuck (21.4 }\end{array}$ \\
\hline $\begin{array}{l}\text { Makulu } \\
\text { Makete }\end{array}$ & $\begin{array}{l}110^{11} \\
\text { Kudu }(46.7) \\
\text { Impala }(34.0)\end{array}$ & No data & Absent & Absent & Absent \\
\hline $\begin{array}{l}\text { Mountain } \\
\text { Zebra }\end{array}$ & $\begin{array}{l}56^{12} \\
\text { Kudu (44.4) } \\
\text { Eland (21.8) }\end{array}$ & Absent & Absent & Absent & Absent \\
\hline Phinda & $\begin{array}{l}294^{13} \\
\text { Nyala }(38.2) \\
\text { Impala }(21.9)\end{array}$ & $\begin{array}{l}185^{14} \\
\text { Nyala }(58.8) \\
\text { Impala }(17.7)\end{array}$ & $\begin{array}{l}458^{14} \\
\text { Wildebeest (33.8) } \\
\text { Zebra (19.6) }\end{array}$ & No data & Absent \\
\hline Shamwari & $\begin{array}{l}32^{15} \\
\text { Impala }(22.1)\end{array}$ & $\begin{array}{l}20^{16} \\
\text { Bushbuck } \\
\text { Tragelaphus } \\
\text { scriptus }(36.2)\end{array}$ & $\begin{array}{l}498^{17} \\
\text { Kudu (41.9) }\end{array}$ & Absent & $\begin{array}{l}103^{18} \\
\text { Kudu (49.5) }\end{array}$ \\
\hline & Kudu (18.7) & $\begin{array}{l}\text { Gemsbok Oryx } \\
\text { gazella }(28.2)\end{array}$ & Eland (16.1) & Absent & Bushbuck (20.4) \\
\hline Timbavati & $\begin{array}{l}47^{19} \\
\text { Impala (55.9) } \\
\text { Kudu }(25.2)\end{array}$ & $\begin{array}{l}168^{19} \\
\text { Impala (68.8) } \\
\text { Kudu (16.0) }\end{array}$ & $\begin{array}{l}642^{19} \\
\text { Giraffe (48.3) } \\
\text { Wildebeest (31.4) }\end{array}$ & $\begin{array}{l}59^{19} \\
\text { Impala (40.5) } \\
\text { Wildebeest (19.5) }\end{array}$ & $\begin{array}{l}19^{19} \\
\text { Kudu }(76.6) \\
\text { Impala (23.4) }\end{array}$ \\
\hline
\end{tabular}

${ }^{1}$ Whateley \& Brooks (1985) ${ }^{2}$ Skinner et al. (1992) ${ }^{3}$ B. de Witt (unpubl. data) ${ }^{4}$ Global Vision International (unpubl. data) ${ }^{5}$ Lehmann et al. (2008) ${ }^{6}$ Kruger (1988) ${ }^{7}$ Mills et al. (2004) ${ }^{8}$ Mills \& Biggs (1993) ${ }^{9}$ Bissett (2007) ${ }^{10}$ M. Hofmeyr (unpubl. data) ${ }^{11} \mathrm{R}$. Brummer (unpubl. data) ${ }^{12}$ D.Parker (unpubl. data) ${ }^{13}$ Hunter (1998) ${ }^{14}$ L. Hunter (unpubl. data) ${ }^{15}$ Hayward et al. (2006b) ${ }^{16}$ Hayward et al. (2006a) ${ }^{17}$ Hayward et al. (2007a) ${ }^{18}$ Hayward et al. (2006c) ${ }^{19}$ Hirst (1969) 
TABle 2 Densities of 14 prey species $\left(\mathrm{km}^{-2}\right)$ in the 12 reserves used in model construction (see text for details).

\begin{tabular}{|c|c|c|c|c|c|c|c|c|c|c|c|c|c|c|}
\hline$\underline{\text { Reserve }}$ & $\begin{array}{l}\text { Blesbok } \\
\text { Damaliscus } \\
\text { pygargus }\end{array}$ & Buffalo & Eland & Gemsbok & Giraffe & $\begin{array}{l}\text { Harte- } \\
\text { beest }\end{array}$ & Impala & Kudu & Nyala & Springbok & $\begin{array}{l}\text { Warthog } \\
\text { Phacochoerus } \\
\text { africanus }\end{array}$ & $\begin{array}{l}\text { Water- } \\
\text { buck }\end{array}$ & $\begin{array}{l}\text { Wilde- } \\
\text { beest }\end{array}$ & Zebra \\
\hline $\begin{array}{l}\text { Hluhluwe- } \\
\text { iMfolozi }^{1}\end{array}$ & 0 & 4.4 & 0 & 0 & 0.7 & 0 & 18 & 1.2 & 6.7 & 0 & 2.2 & 0.6 & 3 & 3.1 \\
\hline Jubatus $^{2}$ & 3.7 & 0 & 0 & 0 & 0 & 0 & 4.9 & 1.2 & 0 & 0 & 1.6 & 0.4 & 5.8 & 3.3 \\
\hline Karongwe $^{3}$ & 0 & 0 & 0 & 0 & 1.4 & 0 & 33.8 & 3.7 & 0.9 & 0 & 4.9 & 4.2 & 2.8 & 2.3 \\
\hline Klaserie $^{4}$ & 0 & 1.7 & $?$ & 0 & 2.4 & 0 & 49 & 1.1 & & 0 & 14.6 & 1.1 & 12.7 & 4.7 \\
\hline Kruger $^{5}$ & 0 & 1 & 0 & 0 & 0.3 & 0 & 14.2 & 0.8 & $?$ & 0 & 0.3 & 0.2 & 0.3 & 0.7 \\
\hline Kwandwe $^{6}$ & 0 & 0.2 & 0.4 & 0.9 & 0.2 & 0.8 & 1.2 & 5.9 & 0 & 1.2 & 4 & 0.6 & 0 & 0.9 \\
\hline Madikwe $^{7}$ & 0.1 & 0.2 & 1.6 & 0.4 & 1.1 & 0.2 & 4.6 & 3.6 & 0 & 0.2 & 2.7 & 1.1 & 4.2 & 3.2 \\
\hline $\begin{array}{l}\text { Makulu } \\
\quad \text { Makete }^{8}\end{array}$ & 0 & 0 & 0.3 & 0 & 0 & 0 & 8.3 & 3.5 & 0 & 0 & $?$ & 2.4 & 0.7 & 0.5 \\
\hline $\begin{array}{c}\text { Mountain } \\
\text { Zebra }^{9}\end{array}$ & 0.8 & 0.6 & 1.4 & 1.7 & 0 & 0 & 0 & 2.5 & 0 & 12.1 & $?$ & 0 & 0 & 0.2 \\
\hline Phinda $^{10}$ & 0 & $?$ & $?$ & 0 & 0.4 & 0 & 11.7 & 1.5 & 12.8 & 0 & 5.2 & $?$ & 3.8 & 3.1 \\
\hline Shamwari ${ }^{11}$ & 1.3 & 0.2 & 0.6 & 0.6 & 0.3 & 0.9 & 4 & 5.2 & 0.2 & 1.4 & 1.3 & 0.4 & 0.6 & 0.9 \\
\hline Timbavati $^{12}$ & 0 & 0 & 0 & 0 & 1.8 & 0 & 10.1 & 0.9 & 0 & 0 & 0.2 & 0.2 & 3.6 & 1.3 \\
\hline Mean & 0.5 & 0.8 & 0.4 & 0.3 & 0.7 & 0.2 & 13.3 & 2.6 & 2.1 & 1.2 & 3.7 & 1 & 3.1 & 2 \\
\hline
\end{tabular}

${ }^{1}$ KwaZulu-Natal Wildlife (unpubl. data; distance sampling) ${ }^{2}$ B. de Witt (unpubl. data; aerial census) ${ }^{3}$ Global Vision International (unpubl. data; aerial) $\quad{ }^{4}$ Kruger (1988; aerial) $\quad{ }^{5}$ South African National Parks (aerial) $\quad{ }^{6}$ Bissett (2007; aerial) $\quad{ }^{7}$ M. Hofmeyr (unpubl. data; aerial) $\quad{ }^{8}$ R. Brummer (unpubl. data; aerial) $\quad{ }^{9} \mathrm{D}$. Parker (unpubl. data; aerial) $\quad{ }^{10}$ Hunter (1998; road strip counts) ${ }^{11}$ J. O’Brien (unpubl. data; road strip) ${ }^{12}$ Hirst (1969; road strip)

approach as explained for the cheetah-only scenario. The $M S Y_{\text {cheetah }}$ was then added to the MSY of the other large predators and the observed densities were again used to calculate the areas required to support the required prey populations. By comparing the areas required for an increase in one cheetah when cheetahs are alone and for an increase of one cheetah when each other predator species is included at a 1:1 ratio we assessed the relative impact of having the other predators in reserves with cheetahs. All model development was conducted using $R$ v. 2.7 (R Development Core Team, 2009).

\section{Results}

\section{In the absence of competing predators}

The predicted mean area required to support a population of 10 cheetahs in the absence of other predators is $203 \pm \mathrm{SE}$ $42 \mathrm{~km}^{2}$, range $48-466 \mathrm{~km}^{2}$ (Table 3). In contrast, existing subpopulations of cheetahs in reserves live at a mean density of 10 cheetahs per $313 \pm$ SE $117 \mathrm{~km}^{2}$ (range 50$2,000)$ in reserves without lions and 10 cheetahs per $729 \pm$ SE $149 \mathrm{~km}^{2}$ in reserves with lions (range 88-6,200; Table 4), with varying degrees of presence/absence of other predator species in both reserve categories. Cheetahs could potentially be conserved in smaller areas if prey populations are augmented annually. Estimated mean costs of augmenting prey populations to permit the conservation of 10 cheetahs in reserves of 100,200 and $300 \mathrm{~km}^{2}$ are c. USD 62,000, 18,000 and 7,000, respectively (Table 3 ).

\section{With other predators present}

The presence of other large predators substantially increases the area required to support cheetahs. The mean area required for a subpopulation of 10 cheetahs in the presence of an equal number of lions is estimated to be $469 \pm$ SE $267 \mathrm{~km}^{2}$. For 15 cheetahs (the recommended minimum size of subpopulations for reserves with lions present) an estimated mean of $703 \pm S E 311 \mathrm{~km}^{2}$ (range 166$2,806 \mathrm{~km}^{2}$; Table 5) is required, given an equal number of lions. The increase in the area required to support cheetahs, i.e. imposed by competing predators, varies among species (analysis of variance, $\mathrm{df}=3, \mathrm{~F}$-ratio $=7.49, \mathrm{P}<0.001$; Table 6). The greatest mean increase is imposed by wild dogs, followed by lions. The mean area required to support 10 cheetahs and 10 individuals of each of the other four large predators is estimated to be $1,616 \pm 594 \mathrm{~km}^{2}$ (or $2,424 \pm \mathrm{SE} 890 \mathrm{~km}^{2}$ for 15 cheetahs and 15 individuals of other species; range, $727-3,739 \mathrm{~km}^{2}$, Table 5).

\section{Existing populations of cheetahs}

The population of cheetahs in small- to medium-sized fenced reserves currently numbers c. 258 individuals, in reserves with a mean size of $267 \pm \mathrm{SE} 54.5 \mathrm{~km}^{2}$, supporting mean subpopulation sizes of $6.61 \pm$ SE 1.17 (Table 4). The most common combination of large predator species in reserves with reintroduced populations of cheetahs is leopards, lions and spotted hyaenas (25.0\% of reserves), with wild dogs only present in $17.5 \%$ of reserves (Table 5). 
TABLE 3 Number of prey and area requirements for 10 cheetahs based on the two most prevalent prey species in their diet (Table 1) in 12 reserves (the bold type denotes which of the two prey species in each area determines the minimum area requirements), and augmentation of prey populations required to conserve 10 cheetahs in areas of 100,200 and $300 \mathrm{~km}^{2}$ assuming other predators are absent (to provide an impression of the potential costs involved if cheetahs were managed at varying densities in different reserve/prey availability scenarios), and (in parentheses) the annual cost of such augmentations based on 2009 live-sale values (Wildlife Ranching South Africa, unpubl. data).

\begin{tabular}{|c|c|c|c|c|c|c|}
\hline \multirow[b]{2}{*}{ Reserve } & \multirow{2}{*}{$\begin{array}{l}\text { Limiting } \\
\text { prey } \\
\text { species }\end{array}$} & \multirow{2}{*}{$\begin{array}{l}\text { Prey } \\
\text { population } \\
\text { required }\end{array}$} & \multirow{2}{*}{$\begin{array}{l}\text { Area needed } \\
\text { for } 10 \\
\text { cheetahs } \\
\left(\mathrm{km}^{2}\right)\end{array}$} & \multicolumn{3}{|c|}{$\begin{array}{l}\text { No. of prey required to augment populations annually, in } \\
\text { reserves of three sizes, with } 10 \text { cheetahs (annual cost of } \\
\text { augmentation, based on } 2009 \text { live sale values; USD) }\end{array}$} \\
\hline & & & & $100 \mathrm{~km}^{2}$ & $200 \mathrm{~km}^{2}$ & $300 \mathrm{~km}^{2}$ \\
\hline \multirow{2}{*}{$\begin{array}{l}\text { Hluhluwe- } \\
\text { iMfolozi }\end{array}$} & Impala & 368 & 20.5 & 0 & 0 & 0 \\
\hline & Nyala & 642 & 95.7 & 0 & 0 & 0 \\
\hline \multirow[t]{2}{*}{ Jubatus } & Kudu & 510 & 408 & $385(126,977)$ & $260(85,727)$ & $135(44,477)$ \\
\hline & Eland & 467 & 466 & $92(63,555)$ & $33(23,102)$ & $14(9,618)$ \\
\hline \multirow[t]{2}{*}{ Karongwe } & Impala & 1,763 & 54.4 & 0 & 0 & 0 \\
\hline & Kudu & 285 & 83.2 & 0 & 0 & 0 \\
\hline \multirow[t]{2}{*}{ Klaserie } & Impala & 1,204 & 24.6 & 0 & 0 & 0 \\
\hline & Waterbuck & 131 & 120 & $22(13,535)$ & 0 & 0 \\
\hline \multirow[t]{2}{*}{ Kruger } & Impala & 806 & 56.8 & 0 & 0 & 0 \\
\hline & Zebra & 286 & 409 & $216(155,038)$ & $73(52,424)$ & $25(18,219)$ \\
\hline \multirow[t]{2}{*}{ Kwandwe } & Kudu & 700 & 119 & $110(36,338)$ & 0 & 0 \\
\hline & Springbok & 191 & 161 & $72(8,257)$ & 0 & 0 \\
\hline \multirow[t]{2}{*}{ Madikwe } & Wildebeest & 235 & 56.1 & 0 & 0 & 0 \\
\hline & Kudu & 386 & 109 & $31(10,055)$ & 0 & 0 \\
\hline \multirow[t]{2}{*}{ Makulu Makete } & Impala & 618 & 74.3 & 0 & 0 & 0 \\
\hline & Kudu & 698 & 200 & $349(115,095)$ & 0 & 0 \\
\hline \multirow[t]{2}{*}{ Mountain Zebra } & Eland & 149 & 103 & $5(3,394)$ & 0 & 0 \\
\hline & Kudu & 555 & 225 & $308(101,773)$ & $61(20,263)$ & 0 \\
\hline \multirow[t]{2}{*}{ Phinda } & Impala & 466 & 39.8 & 0 & 0 & 0 \\
\hline & Nyala & 613 & 47.7 & 0 & 0 & 0 \\
\hline \multirow[t]{2}{*}{ Shamwari } & Kudu & 270 & 51.8 & 0 & 0 & 0 \\
\hline & Impala & 440 & 109 & $38(4,343)$ & 0 & 0 \\
\hline \multirow[t]{2}{*}{ Timbavati } & Impala & 1,112 & 111 & $112(12,919)$ & 0 & 0 \\
\hline & Kudu & 363 & 418 & $276(91,211)$ & $95(31,250)$ & $34(11,264)$ \\
\hline \multirow[t]{2}{*}{$M e a n \pm S E$} & & & $203 \pm 42$ & $168 \pm 51$ & $44 \pm 25$ & $17 \pm 12$ \\
\hline & & & & $(61,874 \pm 19,817)$ & $(17,731 \pm 9,616)$ & $(6,965 \pm 4,608)$ \\
\hline
\end{tabular}

The observed areas in which cheetahs occur are generally smaller than the predicted area requirements, although usually within the range of predicted area requirements for the scenarios presented (Table 5).

The area required to support cheetah populations of any size, given varying scenarios of other predator presence, absence or density can be estimated by multiplying the values in Table 6 (which are the increase in area required to support one cheetah in the presence of one individual of each of four other large predator species) with the area estimates presented for cheetahs in the absence of other predators in Table 3.

\section{Discussion}

\section{Accuracy of our estimates}

The accuracy of our area estimates depends on the quality of the input data and of our underlying assumptions. Two issues may have introduced conservatism into our estimates (i.e. resulting in overestimation of area requirements). Firstly, the estimation of predator diet using observations of carcasses is likely to impose bias by the over-representation of large species and under-representation of small species (Mills, 1992). This phenomenon would probably both increase apparent overlap in diet among the predator species and inflate apparent reliance on large, slow-breeding species, both of which would increase our estimates of the area requirements of predators. The degree of overlap between cheetahs and leopards, for example, may have been particularly exaggerated. Prey profiles presented for leopards do not indicate consumption of small species such as rodents and hyraxes (Procavia capensis, Heterohyrax brucei), which are known to form a significant component of the diet in some areas (Grobler \& Wilson, 1972). Similarly, research from the Kalahari suggests that cheetahs rely more heavily on small species, such as scrub hares Lepus saxatilis and steenbok Raphicerus campestris, than previously recognized 
TABLE 4 Reserve areas, number of cheetahs, and $\mathrm{km}^{2}$ per individual cheetah of existing reintroduced populations of cheetahs in reserves in South Africa without and with lions, and whether the reserves contain leopards, spotted hyaenas or wild dogs (1) or not (o). Reserves are in increasing size within the two sections.

\begin{tabular}{|c|c|c|c|c|c|c|}
\hline Reserve & Area $\left(\mathrm{km}^{2}\right)$ & $\begin{array}{l}\text { No. of } \\
\text { cheetahs }\end{array}$ & $\begin{array}{l}\mathrm{km}^{2} \text { per } \\
\text { cheetah }\end{array}$ & Leopards? & $\begin{array}{l}\text { Spotted } \\
\text { hyaenas? }\end{array}$ & Wild dogs? \\
\hline \multicolumn{7}{|l|}{ Without lions } \\
\hline Kwekwe & 10 & 2 & 5.0 & 0 & 0 & 0 \\
\hline Jubatus & 22 & 3 & 7.3 & 1 & 0 & 0 \\
\hline Hopewell & 27 & 3 & 9.0 & 1 & 0 & 0 \\
\hline Makutsi & 39 & 2 & 19.5 & 1 & 1 & 0 \\
\hline Witwater & 45 & 2 & 22.5 & 1 & 0 & 0 \\
\hline Makulu Makete & 45 & 2 & 22.5 & 1 & 0 & 0 \\
\hline Amakhala & 55 & 8 & 6.9 & 1 & 0 & 0 \\
\hline Hlambanyati & 60 & 4 & 15.0 & 1 & 1 & 1 \\
\hline Bushman Sands & 70 & 2 & 35.0 & 1 & 0 & 0 \\
\hline Greater Kuduland & 80 & 8 & 10.0 & 1 & 0 & 0 \\
\hline Glen Lyon & 100 & 5 & 20.0 & 1 & 0 & 0 \\
\hline Samara & 140 & 7 & 20.0 & 1 & 0 & 0 \\
\hline Mountain Zebra & 214 & 13 & 16.5 & 0 & 0 & 0 \\
\hline Zululand Rhino & 220 & 4 & 55.0 & 1 & 1 & 0 \\
\hline Mkhuze & 400 & 11 & 36.4 & 1 & 1 & 1 \\
\hline Tswalu $2^{*}$ & 800 & 4 & 200.0 & 1 & 0 & 0 \\
\hline$M e a n \pm S E / \%$ & $145.4 \pm 50$ & $5.0 \pm 0.9$ & $31.3 \pm 11.7$ & 8.8 & 25.0 & 12.5 \\
\hline \multicolumn{7}{|l|}{ With lions } \\
\hline Blaauwbosch & 35 & 4 & 8.8 & 1 & 0 & 0 \\
\hline Phumba & 60 & 2 & 30.0 & 1 & 1 & 0 \\
\hline Lalibela & 64 & 2 & 32.0 & 1 & 0 & 0 \\
\hline Mkuze Falls & 80 & 5 & 16.0 & 1 & 1 & 0 \\
\hline Nambiti & 80 & 5 & 16.0 & 1 & 1 & 0 \\
\hline Entabeni & 80 & 2 & 40.0 & 1 & 1 & 0 \\
\hline Karongwe & 80 & 5 & 16.0 & 1 & 1 & 0 \\
\hline Thornybush & 115 & 8 & 14.4 & 1 & 1 & 0 \\
\hline Shambala & 120 & 2 & 60.0 & 1 & 1 & 1 \\
\hline Kuzuko/Addo & 151 & 9 & 16.8 & 1 & 0 & 0 \\
\hline Shamwari & 180 & 7 & 25.7 & 1 & 0 & 0 \\
\hline Greater Mokolo & 200 & 3 & 66.7 & 1 & 0 & 0 \\
\hline Nkomazi & 200 & 2 & 100 & 1 & 0 & 0 \\
\hline Tswalu 1 & 200 & 4 & 50.0 & 1 & 1 & 1 \\
\hline Kwandwe & 210 & 8 & 26.3 & 1 & 0 & 0 \\
\hline Phinda & 210 & 37 & 5.7 & 1 & 1 & 0 \\
\hline Makalali & 260 & 9 & 28.9 & 1 & 1 & 0 \\
\hline Thaba Tholo* & 320 & 20 & 16.0 & 1 & 0 & 0 \\
\hline Welgevonden & 400 & 5 & 80.0 & 1 & 1 & 0 \\
\hline Sanbona & 540 & 6 & 90.0 & 1 & 0 & 0 \\
\hline Pilanesberg & 572 & 2 & 286.0 & 1 & 0 & 1 \\
\hline Madikwe & 620 & 1 & 620.0 & 1 & 1 & 1 \\
\hline Marakele ${ }^{\star}$ & 670 & $?$ & $?$ & 1 & 1 & 0 \\
\hline Hluhluwe-iMfolozi & 960 & 30 & 32 & 1 & 1 & 1 \\
\hline$M e a n \pm S E / \%$ & $267 \pm 9.97$ & $7.73 \pm 1.86$ & $72.9 \pm 27.0$ & 100 & 58.3 & 20.8 \\
\hline Overall mean $\pm S E / \%$ & $218 \pm 36$ & $6.61 \pm 1.17$ & $55.8 \pm 16.9$ & 95 & 45.0 & 17.5 \\
\hline
\end{tabular}

${ }^{\star}$ Reserves with naturally occurring populations of cheetahs that were subsequently enclosed by predator-proof fencing

(M. Mills, unpubl. data). Secondly, some of the prey-density data used in the analyses reflect reduced ungulate populations because of overstocking of predators. For example, prey densities from Jubatus and Karongwe reserves may be lower than normal because of high predator densities (Lehmann et al., 2008).
Conversely, we may have underestimated area requirements for cheetahs in reserves lacking most competing species but in which brown hyaenas Parahyaena brunnea occur. Brown hyaenas are typically dominant over cheetahs (Mills, 2010) and are known to steal kills on occasion (R. Brummer, unpubl. data). However, published data on 
TABLE 5 Percentage of reserves in South Africa containing cheetahs in various combinations of hyaenas, lions, leopards and wild dogs, predicted means (and ranges) of area requirements for 15 cheetahs in the various combinations of predators (assuming equal densities of the species), and observed mean area requirements (and ranges) of cheetahs in reserves when the species has been reintroduced.

\begin{tabular}{|c|c|c|c|}
\hline Species combination & $\begin{array}{l}\% \text { of reserves with } \\
\text { species combination }\end{array}$ & $\begin{array}{l}\text { Mean } \pm \text { SE predicted } \\
\text { area for } 15 \text { cheetahs } \\
\text { (range), } \mathrm{km}^{2}\end{array}$ & $\begin{array}{l}\text { Mean } \pm \text { SE observed area } \\
\text { for } 15 \text { cheetahs } \\
\text { (range) } \mathrm{km}^{2}\end{array}$ \\
\hline Cheetahs & 5.0 & $305 \pm 63(71.6-699)$ & $161 \pm 85(75-247)$ \\
\hline Cheetahs, leopards & 25.0 & $472 \pm 106(196-1,001)$ & $529 \pm 278(103-3,000)$ \\
\hline $\begin{array}{l}\text { Cheetahs, spotted } \\
\text { hyaenas }\end{array}$ & 0 & $610 \pm 223(191-953)$ & \\
\hline Cheetahs, lions & 0 & $703 \pm 311(166-2,806)$ & \\
\hline $\begin{array}{c}\text { Cheetahs, leopards, } \\
\text { spotted hyaenas }\end{array}$ & 5.0 & $749 \pm 275(306-1,254)$ & $559 \pm 266(293-825)$ \\
\hline Cheetahs, wild dogs & 0 & $936 \pm 414(328-2,993)$ & \\
\hline $\begin{array}{l}\text { Cheetahs, leopards, } \\
\text { lions }\end{array}$ & 22.5 & $941 \pm 396(283-2,806)$ & $637 \pm 171(131-1,500)$ \\
\hline $\begin{array}{l}\text { Cheetahs, leopards, } \\
\text { lions, spotted } \\
\text { hyaenas }\end{array}$ & 25.0 & $1,547 \pm 699(391-2,806)$ & $412 \pm 111(85-1,200)$ \\
\hline $\begin{array}{l}\text { Cheetahs, leopards, } \\
\text { spotted hyaenas, } \\
\text { wild dogs }\end{array}$ & 5.0 & $1,625 \pm 960(643-3,546)$ & $385 \pm 160(225-546)$ \\
\hline $\begin{array}{c}\text { Cheetahs, leopards, } \\
\text { lions, wild dogs }\end{array}$ & 2.5 & $2,330 \pm 840(696-3,487)$ & $4,290(4,290)$ \\
\hline $\begin{array}{l}\text { Cheetahs, lions, } \\
\text { leopards, spotted } \\
\text { hyaenas, wild dogs }\end{array}$ & 10.0 & $2,424 \pm 890(727-3,739)$ & $2,858 \pm 2,149(480-9,300)$ \\
\hline
\end{tabular}

the frequency and severity of kleptoparasitism of cheetah kills by brown hyaenas are not available and so we were not able to model the impacts. In areas where other competitively superior large predators occur (notably spotted hyaenas) the impacts of brown hyaenas on cheetahs are likely to be negligible by virtue of the former suppressing numbers of the latter. However, where cheetahs and brown hyaenas are the only large predators present, kleptoparasitism by the latter may increase the area requirements for cheetahs.

There was variation among reserves in the methods used to count prey that could introduce error into estimates of area requirements. Ground-based sampling may result in better estimates of small species than aerial censuses. However, the species used in modelling were the top two species in the diets of predators, which were almost invariably medium- to large-sized species (i.e. impala-size; 45-6o kg) or larger, except for Shamwari and Kwandwe where bushbuck Tragelaphus scriptus $(36-60 \mathrm{~kg})$ and springbok $(37-41 \mathrm{~kg})$ are key components of the diets of some predator species. Consequently, the use of various census techniques is unlikely to have a significant impact on minimum area estimates.

The prey profile of male and female cheetahs tends to differ, the former typically consuming larger prey than the latter (Bissett, 2007). Most data on the diet of cheetahs did not separate data for males and females and thus repre- sented prey profiles of typical gender ratios. Extrapolating from overall cheetah prey profiles is likely to provide an accurate representation of what prey populations would be required to support a typically structured subpopulation of cheetahs. However, in small reserves sex ratios of cheetahs may be skewed, either because of a management preference for a certain number of individuals of either sex or by chance. If the sex ratios of cheetahs are skewed the impacts on certain prey species may differ, depending on the relative over-abundance of males (and particularly coalition males) versus females. With an unusually high proportion of males in a cheetah subpopulation one would expect larger area requirements because of the probable prevalence of larger species in their diet. Area requirements would probably more closely approximate the minimum imposed by the larger of the two primary prey species in the prey profiles presented. Conversely, if the gender ratio is skewed towards females then the area requirements could be significantly lower, and would probably more closely approximate those imposed by the smaller of the two primary prey species in the prey profiles presented. A prevalence of males in the population would probably increase the degree of overlap of diet between cheetahs and large predators, especially lions, whereas a prevalence of females would probably increase the dietary overlap with smaller predators such as wild dogs.

Some of the sample sizes of kills used to estimate prey profiles for some predator species were relatively small 
TABLE 6 The extent of dietary overlap between cheetahs and four other large predator species (calculated using Pianka's index, see text for details) in 12 reserves, and the predicted increase in area required to support one cheetah if one individual of the other large predator species is present, based on the first (Area $\left.\mathrm{Sp}_{1}\right)$ and second (Area $\mathrm{Sp}_{2}$ ) most $_{\mathrm{prevalent}}$ prey species in the cheetah's diet in each reserve (Table 1).

\begin{tabular}{|c|c|c|c|c|c|c|c|c|c|c|c|c|}
\hline Reserve & $\begin{array}{l}\text { Lion } \\
\text { Dietary } \\
\text { overlap }\end{array}$ & Area $_{\mathrm{Sp} 1}$ & Area $_{\mathrm{Sp} 2}$ & $\begin{array}{l}\text { Wild dog } \\
\text { Dietary } \\
\text { overlap }\end{array}$ & Area $_{S p 1}$ & Area $_{\mathrm{Sp} 2}$ & $\begin{array}{l}\text { Leopard } \\
\text { Dietary } \\
\text { overlap }\end{array}$ & Area $_{S p 1}$ & Area $_{\mathrm{Sp} 2}$ & $\begin{array}{l}\text { Spotted } \\
\text { hyaena } \\
\text { Dietary } \\
\text { overlap }\end{array}$ & Area $_{\mathrm{Sp} 1}$ & Area $_{\mathrm{Sp} 2}$ \\
\hline $\begin{array}{l}\text { Hluhluwe- } \\
\text { iMfolozi }\end{array}$ & 0.29 & 1.52 & 1.27 & 0.79 & 3.10 & 1.50 & 0.96 & 1.72 & 1.75 & 0.53 & 1.19 & 1.57 \\
\hline Jubatus & Absent & & & Absent & & & Absent & & & Absent & & \\
\hline Karongwe & 0.22 & 1.06 & 1.59 & Absent & & & No data & & & No data & & \\
\hline Klaserie & No data & & & No data & & & 0.99 & 2.11 & 2.22 & No data & & \\
\hline Kruger & 0.59 & 2.17 & 4.09 & 0.77 & 3.09 & 1.00 & 0.81 & 2.47 & 1.00 & 0.27 & 1.23 & 1.00 \\
\hline Kwandwe & 0.80 & 2.41 & 1.00 & 0.97 & 3.03 & 1.13 & No data & & & Absent & & \\
\hline Madikwe & 0.92 & 2.30 & 3.77 & 0.74 & 3.04 & 1.00 & 0.75 & 1.86 & 1.37 & No data & No data & No data \\
\hline $\begin{array}{l}\text { Makulu } \\
\text { Makete }\end{array}$ & Absent & & & Absent & & & No data & & & Absent & & \\
\hline $\begin{array}{c}\text { Mountain } \\
\text { Zebra }\end{array}$ & Absent & & & Absent & & & Absent & & & Absent & & \\
\hline Phinda & 0.57 & 2.08 & 1.21 & Absent & & & 0.92 & 2.45 & 1.79 & No data & & \\
\hline Shamwari & 0.50 & 1.14 & 5.32 & 0.71 & 1.73 & 4.08 & 0.53 & 2.11 & 1.00 & & & \\
\hline Timbavati & 0.20 & 1.04 & 1.28 & 0.63 & 1.70 & 4.27 & 0.95 & 2.30 & 1.43 & 0.94 & 1.53 & 1.36 \\
\hline$M e a n \pm S E$ & 0.51 & $1.72 \pm 0.21$ & $2.44 \pm 0.59$ & 0.77 & $2.62 \pm 0.28$ & $2.16 \pm 0.64$ & 0.84 & $2.15 \pm 0.11$ & $1.51 \pm 0.17$ & 0.58 & $1.32 \pm 0.11$ & $1.31 \pm 0.17$ \\
\hline
\end{tabular}


(minimum 19 kills, mean $164 \pm$ SE 27 , maximum 642) and the corresponding prey profiles (Table 1 ) should be treated with caution. For example, the atypical prey profile of wild dogs from Timbavati (suggesting an unusually high prevalence of $76.6 \%$ of kudu in the diet) was based on a sample of 19 kills and may have thus resulted in overestimation of the area requirements for the species in that reserve.

\section{Large areas are required to support reintroduced cheetah populations}

Our estimates emphasize that large areas are required for the reintroduction and conservation of cheetahs, particularly in the presence of competing predators. The PHVA for cheetahs in South Africa indicated that 20 subpopulations of cheetahs of at least 10 individuals would be required to preserve $90 \%$ of the heterozygosity of free-ranging cheetah populations in the absence of lions, or 10 subpopulations of 15 individuals in the presence of lions (Lindsey et al., 2009a). An estimated mean area of $203 \mathrm{~km}^{2}$ is required to support 10 cheetahs in the absence of lions, and an estimated mean area of $2,424 \mathrm{~km}^{2}$ is required to support 15 cheetahs in the presence of the complete guild of other large predators. These areas are larger than 65 and $100 \%$ of reserves, respectively, currently containing reintroduced populations of cheetahs in South Africa.

\section{Carrying capacities are influenced primarily by prey densities}

Area requirements of cheetahs vary significantly, primarily because of the wide variation in the density of key prey species. In some cases relatively small areas are able to support sizeable subpopulations of cheetahs: in 50\% of scenarios presented $<100 \mathrm{~km}^{2}$ would be required to support 10 cheetahs in the absence of lions and, in some circumstances (e.g. with the Hluhluwe-iMfolozi Park prey profiles), 15 cheetahs could be conserved in the presence of equal densities of other predators in areas $<1,000 \mathrm{~km}^{2}$. The smallest area requirements for cheetahs were predicted for low-lying coastal reserves in KwaZulu-Natal and the Eastern Cape, which have high densities of cheetah prey species, nyala and impala, and kudu and bushbuck, respectively. However, in reserves with low prey densities large areas are required to support cheetahs even in the absence of other predator species.

\section{Most reserves are stocked at or beyond carrying capacity}

The large area requirements of cheetahs and the relatively small size of most fenced reserves in South Africa means that cheetahs and other predators are often likely to be stocked at densities approaching, or in some cases exceed- ing, what the prey populations in those reserves can support. Correspondingly, prey population declines have been observed in some fenced reserves and cheetahs have been implicated as the cause. In addition to the observed prey declines in Suikerbosrand (Pettifer, 1981), cheetahs caused local extinction of blesbok (c. 60 individuals to o in 2.5 years) and ostriches Struthio camelus (c. 8 to o in the same period) and ongoing declines of impala (193 to 120 during 2006-2008) and kudu (45 to 31) populations in Jubatus Reserve (B. de Witt, unpubl. data; L. Robinson, pers. comm.), and sharp declines in bushbuck numbers in Makulu Makete (R. Brummer, unpubl. data). In all three instances cheetahs were the only large predator present, except for occasional brown hyaenas. Similarly, reintroduced populations of lions have caused prey population declines at several sites (e.g. Pilanesberg; Tambling \& du Toit, 2005), and wild dogs have generally been removed from the smaller reserves into which they were reintroduced because of excessive impacts on prey populations (Power, 2002; Hayward et al., 2008; Lehmann et al., 2008; Davies-Mostert et al., 2009). An ongoing debate regarding the management of the metapopulation of wild dogs has been the necessity and/or acceptability of intensive management of their numbers following reintroductions (Davies-Mostert et al., 2009). Our results suggest that because of the high densities at which cheetahs and other predators are stocked, regular management intervention is advisable to prevent carrying capacities being exceeded. This occurred at Mountain Zebra National Park during 2010, with 19 cheetahs removed to reduce the population to 13 individuals (D. Parker, unpubl. data).

Achieving viability in the managed metapopulation will be difficult

The large area requirement of cheetahs, particularly in the presence of other predator species, suggests that developing subpopulations of cheetahs of sufficient size to attain viability in the managed metapopulation will be challenging. There is a shortage of large reserves in South Africa: of the areas in which cheetahs have been reintroduced (or fencing constructed around free-ranging populations, excluding Kruger and Kgalagadi) none are larger than $1,000 \mathrm{~km}^{2}$, six $(15.0 \%)$ are $>500 \mathrm{~km}^{2}$, and 17 are $<100 \mathrm{~km}^{2}$ (42.5\%). Consequently, most reserves support small subpopulations of cheetahs: $85.0 \%$ support $<10$ and $62.5 \%$ support five or fewer. Of the reserves without lions, only two support $>10$ cheetahs and, of the reserves with lions, only three support $>15$ cheetahs. Experiences from the metapopulation of wild dogs in South Africa suggest that small subpopulations are of limited conservation value and have potential to affect the metapopulation negatively (Davies-Mostert et al., 2009). Very small subpopulations require frequent augmentation to prevent inbreeding and 
in response to stochastic population declines. Consequently, such subpopulations may act as sinks for the wider metapopulation, without conferring commensurate demographic or genetic benefits (Davies-Mostert et al., 2009).

\section{Strategies are required to increase the carrying capacity of reserves for cheetahs}

Given the shortage of sufficiently large reintroduction sites, innovative strategies may be required to increase the carrying capacity of reserves for cheetahs and/or to increase the size of reserves. Several options are available, including:

(1) Augmentation of prey populations Smaller areas could potentially be used to support larger subpopulations of cheetahs than predicted from prey availability if prey populations are augmented regularly. Some reserve managers have augmented prey populations to permit retention of diverse and relatively high density predator populations. For example, large numbers of several ungulate species were reintroduced into De Beers Venetia Limpopo Nature Reserve following declines imposed by the combined impact of the six large $(>20 \mathrm{~kg})$ predator species present there (H. Davies-Mostert, unpubl. data). For the lower prey density scenarios presented, a mean annual augmentation of prey populations by 168 animals (range 22-477) for a mean cost of c. USD 62,000 (range c. USD 4,000-191,000) would permit the stocking of 10 cheetahs in an area of $100 \mathrm{~km}^{2}$. Overstocking of ungulates would not be advisable because the likelihood of ecological degradation and therefore augmentation should be limited to replenishing populations if they are depleted by predation.

(2) Manipulation of the densities of competing predators The area required to support cheetahs could be reduced by manipulating the densities of competing predators. However, the primary land use of reserves of sufficient size for the reintroduction of cheetahs is typically ecotourism, for which predators are crucial attractions (Lindsey et al., 2009c). Nonetheless, if the relative density of predators was manipulated such that competitors were stocked at densities lower than those of cheetahs, competition with cheetahs for prey would be minimized. In addition, mortality of cheetahs through predation would be reduced. Such manipulation would be particularly important for predator species whose diets overlap the most with cheetahs, leopards and wild dogs (Hayward \& Kerley, 2008). Conversely, reducing the numbers of cheetahs would be important for increasing the carrying capacity of reserves for wild dogs.

(3) Promoting the formation of larger reserves of the 40 small- to medium-sized fenced reserves containing cheetahs, 33 are privately owned (Lindsey et al., 2009b). Private game reserves are typically created through the formation of multi-owner conservancies, or through the purchase and conglomeration of adjacent properties by single landowners or corporations (Lindsey et al., 2009c). Encouraging the formation of more and larger conservancies would increase the availability of potential reintroduction sites and thus improve the prospects of establishing a viable metapopulation. The introduction of tax-breaks for wildliferanchers whose land forms part of conservancies or the provision of preferential access to permits for wildlife utilization to such farmers, and withholding of such benefits from ranchers who remain isolated and retain perimeter fencing should be considered as a potential means of encouraging the consolidation of individual game ranches into conservancies or private reserves. Such incentives would benefit government because conservancies are generally more profitable than small ranches, and because they confer a variety of ecological benefits including increased ecological resilience, reduced prevalence of undesirable land and wildlife management practices, and provide incentives for the effective re-establishment and conservation of indigenous biodiversity (Lindsey et al., 2009c).

(4) Increasing connectivity with free-ranging cheetah populations In areas where cheetahs in reserves exist within the distribution of free-ranging populations of cheetahs the effective size of reintroduced populations could be increased by establishing connectivity with the free-ranging population. This could be achieved through the use of fencing permeable to cheetahs, as is used in part of Tswalu Kalahari Reserve (listed as Tswalu 2 in Table 4; G. Van Dyk, pers. comm.). However, such an approach would only be possible in reserves lacking other large predators because of the potential for conflict with neighbouring farmers if species such as lions, spotted hyaenas or wild dogs escape. Furthermore, reserve owners who have purchased and reintroduced cheetahs may not be willing to risk losing them by allowing movement into adjacent unprotected lands.

\section{Conclusions}

By presenting a range of scenarios based on varying cheetah prey profiles, prey densities and presence/absence of competing predator species, we have provided a means for reserve managers to gain an understanding of the likely approximate area requirements of cheetahs across a variety of ecological circumstances. The large estimated area requirements of cheetahs, particularly in the presence of competing predators, suggests that achieving viability in the managed metapopulation will be difficult, stressing the importance of managing reintroduced predator populations to prevent carrying capacities being exceeded, and indicates that innovative strategies to increase the carrying capacity or size of reserves will be required for effective management of a metapopulation of cheetahs in South Africa. 


\section{Acknowledgements}

We thank the Howard Buffett Foundation for making this research possible, Wildlife Ranching South Africa, John O'Brien, Simon Naylor and Geoff Clinning for the provision of background information, and Gus Mills for useful comments. We also thank all of the reserves for providing or acting as sources of data.

\section{References}

Bissett, C. (2007) The feeding and spatial ecologies of the large carnivore guild on Kwandwe private game reserve. $\mathrm{PhD}$ thesis, Rhodes University, South Africa.

Bissett, C. \& Bernard, R.T.F. (2007) Habitat selection and feeding ecology of the cheetah (Acinonyx jubatus) in thicket vegetation: is the cheetah a savannah specialist? Journal of Zoology, 271, 310-317.

Bотнма, J. (2002) Game Ranch Management. Van Schaik, Pretoria, South Africa.

Breitenmoser, U. (1998) Large predators in the Alps: rise and fall of man's competitors. Biological Conservation, 83, 279-289.

Broomhall, L.S., Mills, M.G.L. \& du Toit, J.T. (2003) Home range and habitat use by cheetahs (Acinonyx jubatus) in the Kruger National Park. Journal of Zoology, 261, 119-128.

Caro, T.M. (1994) Cheetah of the Serengeti Plains: Group Living in an Asocial Species. University of Chicago Press, Chicago, USA.

Castley, J., Knight, M., Mills, M.G.L. \& Thouless, C. (2002) Estimation of the lion (Panthera leo) population in the southwestern Kggalagadi Transfrontier Park using a capture-recapture survey. African Zoology, 37, 27-34.

Caughley, G. (1977) An Analysis of Vertebrate Populations. John Wiley \& Sons, Chichester, UK.

Caughley, G. \& Krebs, C. (1983) Are big mammals simply little mammals writ large? Oecologia, 59, 7-17.

Coe, M., Cumming, D. \& Phillipson, J. (1976) Biomass and production of large African herbivores in relation to rainfall and primary production. Oecologia, 22, 341-354.

Davies-Mostert, H., Mills, M.G.L. \& Macdonald, D. (2009) A critical assessment of South Africa's managed metapopulation recovery strategy for African wild dogs and its value as a template for large carnivore conservation elsewhere. In Reintroduction of Top Order Predators (eds M. Hayward \& M. Somers), WileyBlackwell, London, UK.

Durant, S., Marker, L., Purchase, N., Belbachir, F., Hunter, L., P ACKer, C. et al. (2008) Acinonyx jubatus. In IUCN Red List of Threatened Species v. 2010.4. Http:// www.iucnredlist.org [accessed 12 April 2011].

Frame, G. (1999) Cheetah. In The Encyclopedia of Mammals (ed. D.W. Macdonald), pp. 58-62. Andromeda Oxford Limited, Oxford, UK.

Funston, P.J. (2008) Conservation and management of lions in southern Africa: status, threats, utilization and the restoration option. In Management and Conservation of Large Carnivores in West and Central Africa (eds B. Croes, R. Buij, H. de Iongh \& H. Bauer), pp. 109-131. Institute of Environmental Sciences, Leiden, The Netherlands.

Funston, P., Mills, M.G.L., Biggs, H. \& Richardson, P. (1998) Hunting by male lions: ecological influences and socio-ecological implications. Animal Behaviour, 56, 1333-1345.

Grobler, J.H. \& Wilson, V.J. (1972) Food of the leopard Panthera pardus (Linn.) in the Rhodes Matopos National Park, Rhodesia, as determined by faecal analysis. Arnoldia, 5, 1-10.
Gusset, M., Ryan, S., Hofmeyr, M., van Dyk, G., DaviesMostert, H., Graf, J. et al. (2008) Efforts going to the dogs? Evaluating attempts to reintroduce endangered wild dogs in South Africa. Journal of Applied Ecology, 45, 100-108.

Hayward, M., Hayward, G., Druce, D. \& Kerley, G. (2008) Do fences constrain predator movements on an evolutionary scale? Home range, food intake and movement patterns of large predators reintroduced to Addo Elephant National Park, South Africa. Biodiversity and Conservation, 18, 887-904.

Hayward, M.W., Henschel, P., O’Brien, J., Hofmeyr, M., Balme, G. \& Kerley, G.I.H. (2006a) Prey preferences of the leopard (Panthera pardus). Journal of Zoology, 270, 298-313.

Hayward, M.W., Hofmeyr, M., O’Brien, J. \& Kerley, G.I.H. (2006b) Prey preferences of the cheetah Acinonyx jubatus: morphological limitations or the need to capture rapidly consumable prey before kleptoparasites arrive? Journal of Zoology, $270,615-627$.

Hayward, M.W., Hofmeyr, M., O’Brien, J. \& Kerley, G.I.H. (2007a) Testing predictions of the prey of the lion (Panthera leo) derived from modelled prey preferences. Journal of Wildlife Management, 71, 1567-1575.

Hayward, M.W. \& Kerley, G.I.H. (2008) Prey preferences and the conservation status of Africa's large predators. South African Journal of Wildlife Research, 38, 93-108.

Hayward, M.W., O'Brien, J., Hofmeyr, M. \& Kerley, G. (2006) Prey preferences of the African wild dog Lycaon pictus (Canidae: Carnivora): ecological requirements for conservation. Journal of Mammalogy, 87, 1122-1131.

Hayward, M.W., O'Brien, J. \& Kerley, G.I.H. (2007b) Carrying capacity of large African predators: predictions and tests. Biological Conservation, 139, 219-229.

Hirst, S.M. (1969) Predation as a limiting factor of large ungulate populations in a Transvaal lowveld nature reserve. Zoologica Africana, 4, 199-230.

HUNTER, L. (1998) The behavioural ecology of reintroduced lions and cheetahs in the Phinda Resource Reserve, KwaZulu-Natal, South Africa. PhD thesis, University of Pretoria, South Africa.

Hunter, L.T.B., Pretorius, L., Carlisle, M., Walker, C., Slotow, R. \& S Kinner, J.D. (2007) Restoring lions Panthera leo to northern KwaZulu-Natal, South Africa: short-term biological and technical success but equivocal long-term conservation. Oryx, 41, 196-204.

KR U GER, J.E. (1988) Interrelationships between the larger carnivores of the Klaserie Private Nature Reserve with special reference to the leopard and the cheetah. MSc thesis, University of Pretoria, Pretoria, South Africa.

Lehmann, M., Funston, P., Owen, C. \& Slotow, R. (2008) The feeding ecology of lions Panthera leo on a small reserve. South African Journal of Wildlife Research, 38, 66-78.

Lindsey, P., Cilliers, D., Davies-Mostert, H. \& Marnewick, K. (2009a) Draft Strategy for a Managed Metapopulation of Cheetahs Acinonyx jubatus in South Africa. Endangered Wildlife Trust report, Johannesburg, South Africa.

Lindsey, P.A. \& Davies-Mostert, H.T. (eds) (2009) South African Action Plan for the Conservation of Cheetahs and African Wild Dogs. Report from a National Conservation Action Planning Workshop for South Africa. Endangered Wildlife Trust, Johannesburg, South Africa.

Lindsey, P.A., DU Toit, J.T. \& Mills, M.G.L. (2004) Area and prey requirements of African wild dogs under varying habitat conditions: implications for reintroductions. South African Journal of Wildlife Research, 34, 77-86. 
Lindsey, P., Marnewick, K., Davies-Mostert, H., Rhese, T., Mills, M.G.L., Brummer, R. et al. (2009b) Population and Habitat Viability Assessment for Cheetahs in South Africa. IUCN Conservation Breeding Specialist Group and Endangered Wildlife Trust Report, Johannesburg, South Africa.

Lindey, P., Masterson, C., Romañach, S. \& Beck, A. (in press) The ecological, financial and social issues associated with fencing as a conservation tool in southern Africa. In Fencing for Conservation: Restriction of Evolutionary Potential or a Riposte to Threatening Processes? (eds M. Somers \& M. Hayward), Springer, New York, USA.

Lindsey, P., Romañach, S. \& Davies-Mostert, H. (2009c) The importance of conservancies for enhancing the value of game ranch land for large mammal conservation in southern Africa. Journal of Zoology, 277, 99-105.

Linnell, J.D.C., Swenson, J.E. \& Andersen, R. (2001) Predators and people: conservation of large carnivores is possible at high human densities if management policy is favourable. Animal Conservation, 4, 345-349.

Marker, L.L., Dickman, A.J., Mills, M.G.L., Jeo, R.M. \& MACDonALD, D.W. (2008) Spatial ecology of cheetahs on northcentral Namibian farmlands. Journal of Zoology, 274, 226-238.

Marnewick, K., Beckhelling, A., Cilliers, D., Lane, E., Mills, M.G.L., Herring, K. et al. (2007) The status of the cheetah in South Africa. In The Status and Conservation Needs of the Cheetah in Southern Africa (eds C. Breitenmoser \& S. Durant), pp. 22-31. Cat News Special Edition, IUCN, Gland, Switzerland.

Marnewick, K., Hayward, M., Cilliers, D. \& Somers, M. (2009) Survival of cheetahs relocated from ranchland to fenced protected areas in South Africa. In Reintroduction of Top Order Predators (eds M. Hayward \& M. Somers), pp. 282-306. WileyBlackwell, Oxford, UK.

Mills, M.G.L. (1992) A comparison of methods used to study food habits of large African carnivores. In Wildlife 2001: Populations (eds D. McCullough \& R.H. Barrett), pp. 1112-1124. Elsevier Applied Sciences, London, UK.

Mills, M.G.L. (2010) Brown Hyaena (Parahyaena brunnea). IUCN Hyaena Specialist Group. Http://www.hyaenidae.org/thehyaenidae/brown-hyaena-parahyaena-brunnea.html [accessed August 2010].

Mills, M.G.L. \& Biggs, H.C. (1993) Prey apportionment and related ecological relationships between large carnivores in the Kruger National Park. Symposia of the Zoological Society of London, 65, 253-268.

Mills, M.G.L., Broomhall, L.S. \& Du Toit, J.T. (2004) Cheetah Acinonyx jubatus feeding ecology in the Kruger National Park and a comparison across African savannah habitats: is the cheetah only a successful hunter on open grassland plains? Wildlife Biology, 10, 177-186.

Mills, M.G.L., Ellis, S., Woodroffe, R., Maddock, A., Stander, P., Rasmussen, G. et al. (1998) Population and Habitat Viability Analysis for the African Wild Dog (Lycaon pictus) in Southern Africa. Unpublished IUCN/Species Survival Commission Conservation Breeding Specialist Group workshop report, Pretoria, South Africa.

Owen-Smith, N. \& Mills, M.G.L. (2008) Predator-prey size relationships in an African large-mammal food web. Journal of Animal Ecology, 77, 173-183.
Pettifer, H. (1981) Aspects of the ecology of cheetahs on the Suikerbosrand Nature Reserve. In Worldwide Furbearer Conference Proceedings (eds J. Chapman \& D. Pursely), pp. 1121-1142. International Association of Fish and Wildlife, Virginia, USA.

Pianka, E.R. (1973) The structure of lizard communities. Annual Review of Ecology and Systematics, 4, 53-74.

Power, R.J. (2002) Prey selection of lions Panthera leo in a small, enclosed reserve. Koedoe, 45, 67-75.

Radloff, F.G.T. \& du Toit, J.T. (2004) Large predators and their prey in a southern African savannah: a predator's size determines its prey size range. Journal of Animal Ecology, 73, 410-423.

Redfern, J.V., Viljoen, P.C., Kruger, J.M. \& Getz, W.M. (2002) Biases in estimating population size from an aerial census: a case study in the Kruger National Park, South Africa. South African Journal of Science, 98, 455-461.

R Development Core Team (2008) R: A Language and Environment for Statistical Computing. R Foundation for Statistical Computing, Vienna, Austria. Http://www.R-project.org/ [accessed August 2010].

Skinner, J.D., Funston, P.J., van Aarde, R.J., van Dyk, G. \& HAUPT, M.A. (1992) Diet of spotted hyaenas in some mesic and arid southern African game reserves adjoining farmland. South African Journal of Wildlife Research, 22, 119-121.

Stuart, C. \& STUART, T. (1991) Field Guide to the Mammals of Southern Africa. Struik, Cape Town, South Africa.

Tambling, C. \& DU Toit, J. (2005) Modelling wildebeest population dynamics: implications of predation and harvesting in a closed system. Journal of Applied Ecology, 42, 431-441.

Whateley, A. \& Brooks, P.M. (1985) The carnivores of the Hluhluwe and Umfolozi Game Reserves: 1973-1982. Lammergeyer, $35,1-27$.

Woodroffe, R. \& Ginsberg, J.R. (1998) Edge effects and the extinction of populations inside protected areas. Science, 280, $2126-2128$.

\section{Biographical sketches}

Peter Lindey works throughout southern Africa on a variety of topics including, inter alia, wildlife-based land uses, the bushmeat trade and predator conservation. CRAIG TAMBLING's research interests include predator-prey interactions in African ecosystems and the impact that these interactions have on the population dynamics of both prey and predators. Rox BRUMMER is currently working on noninvasive sampling methods for mammals, primarily using detection dogs, for the Wildlife Conflict Mitigation Programme of the Endangered Wildlife Trust. Kelly Marnewick manages the Carnivore Conservation Programme at the Endangered Wildlife Trust, with a special interest in carnivores outside protected areas. MATT HAYW A RD works as a regional ecologist for the Australian Wildlife Conservancy where he is researching the reintroduction ecology of endangered marsupials. He is also involved in research on predator-prey dynamics in South Africa. Harriet Davies-Mostert is an ecologist specializing in large carnivores, with a special interest in the functioning of natural and managed metapopulations and protected area connectivity. DAN PARKER is a wildlife biologist who is particularly interested in the ecology of large African predators. 